\title{
SUBVERSI TERHADAP PEMERINTAH INDONESIA DALAM DISKURSUS DEMOKRASI
}

\author{
Karman \\ Badan Penelitian dan Pengembangan Sumber Daya Manusia, Kementerian Komunikasi dan Informatika \\ Jl. Medan Merdeka Barat No. 9 Jakarta 10110 \\ No. Telp./HP: 082188397473 \\ E-mail: karman@kominfo.go.id
}

Naskah diterima tanggal 22 Februari 2016, direvisi tanggal 4 April 2016, disetujui tanggal 10 Mei 2016

\section{SUBVERSION TOWARDS INDONESIAN GOVERNMENT IN DISCOURSE OF DEMOCRACY}

\begin{abstract}
Democratization in developing countries gets a challenge from Islamic fundamentalists. ICT provides an important opportunity for the rise of subversion against a democratic government. This article deals with construction of fundamentalists of Islamic groups in Indonesia towards democracy via the Internet. The goal of this study is to know their construction in the discourse of democracy. This research was using the method of discourse analysis with the model introduced by Leeuwen (2008). This research shows that the fundamentalists construct democracy on the basis of theology arguments (i.e.: democracy is a "kufr" system, idolatry, forbidden, and Islam-based invalid system) and bad effects of democracy. Democracy is a colonization tool of Western countries. It creates accompliceship between the rich and the powerful. Fundamentalists regard democracy as a "religion". The Indonesian government is represented as "kafir (non-believer)/murtad(apostate)", "colonialist's accomplice", "pharaoh". Fundamentalist's internet use becomes a challenge for the government with the subversion discourse emergence.
\end{abstract}

Keywords: subversion, fundamentalist group, construction, democracy.

\begin{abstract}
Abstrak. Demokratisasi di negara-negara berkembang termasuk Indonesia mendapat tantangan kelompok Islam fundamentalis. Pembangunan ICT memberikan kesempatan bangkitnya wacana subversi mereka terhadap pemerintah demokratis. Penelitian ini membahas bagaimana konstruksi kelompok Islam fundamentalis di Indonesia terhadap demokrasi melalui internet. Tujuan penelitian ini adalah mengetahui konstruksi mereka dalam wacana (discourse) demokrasi. Metode penelitian adalah analisis wacana dengan model yang diperkenalkan oleh Leeuwen (2008). Hasil penelitian menunjukkan bahwa kelompok fundamentalis mengonstruksi demokrasi atas dasar argumen teologi-demokrasi itu sistem kufur, thaghut, batil, haram, dan dampak buruk sosialekonomi-politik sebagai alat penjajahan Barat yang menciptakan perselingkuhan pengusaha dan penguasa. Fundamentalis radikal menganggap demokrasi itu "agama". Pemerintah direpresentasikan sebagai orang "kafir/murtad", "antek penjajah", "firaun". Penggunaan internet kelompok fundamentalis memberikan tantangan bagi pemerintah dengan munculnya wacana subversi tadi.
\end{abstract}

Kata kunci: subversi, kelompok fundamentalis, konstruksi, demokrasi. 


\section{PENDAHULUAN}

Indonesia adalah negara demokrasi di dunia yang dibuktikan dengan adanya pemilihan umum/pemilu dan adanya kompetisi antarindividu/partai politik; partisipasi politik; kebebasan sipil, politik, bicara, dan pers, berorganisasi serta adanya lembaga demokrasi (Diamond, 2006; UNDP and BAPPENAS, 2009; Gaffar, 1996). Demokrasi tidak bisa lepas dari peran pemikiran agama. Penelitian sebelumnya menunjukkan, agama merupakan variabel yang menentukan perilaku politik (Liddle, 1997; Huntington, 1996). Sikap muslim Indonesia dalam merespon demokrasi terbagi dua: kelompok Islam yang menerima demokrasi dan kelompok Islam yang menolak demokrasi (Haqqani, 2013). Umat Islam yang menerima demokrasi disebut kelompok Islam moderat atau kelompok Islam substantialist. Sebaliknya, kelompok Islam yang menolak demokrasi disebut kelompok Islam fundamentalis atau Islam revivalist. Hasil tinjauan literatur (Hefner, 2001; Mujani, 2007; Widodo, 2008; Muhtadi, 2009; Dallmayr, 2011; Muthohirin, 2014) menunjukkan, pertama, fenomena demokrasi dan Islam lebih banyak didekati dari ilmu politik. Umumnya, peneliti melihat fenomena politik umat Islam berangkat dari keberpihakan mereka terhadap demokrasi itu sendiri. Peneliti gagal memeroleh pemahaman (verstehen) terhadap aksi sosial kelompok fundamentalis.

Kedua, penelitian terdahulu terjebak pada logika berpikir yang bersifat oposisi biner (binnary oposition) dalam melihat fenomena umat Islam: Islam fundamentalis, ekstremis atau Islam radikal versus Islam moderat atau Islam liberal; Islam textualist versus Islam kontekstual atau Islam kultural; Islam eksklusif versus Islam inklusif. Padahal, cara berpikir tiap kelompok Islam tidaklah tunggal. Mereka bertentangan satu dengan lainnya seperti tampak dari penelitian Lestari (2014) yang mengkaji relasi Islam dan demokrasi dengan tema wacana demokrasi dalam public sphere komunikasi politik di organisasi Islam Indonesia. Organisasi yang dimaksud dalam penelitiannya adalah Hizbut Tahrir Indonesia
(HTI), Front Pembela Islam (FPI), Muhammadiyah, dan Nahdlatul Ulama (NU). Pandangan buram terhadap realitas ragam kelompok fundamentalis terlihat juga ketika Kementerian Komunikasi dan Informatika memblokir situs Islam radikal yang justru berakibat penolakan dari masyarakat luas. Pemerintah dinilai tidak memiliki peta gerakan Islam di Indonesia.

Keterbatasan penelitian tersebut mendorong peneliti untuk mengkaji masalah di atas dengan menekankan pada unsur pesan dan saluran komunikasi. Fokus penelitian ini mengkaji kelompok-kelompok Islam yang tergolong fundamentalis dan menekankan aspek konstruksi mereka terhadap demokrasi. Kelompok fundamentalis yang dimaksud adalah Jamaah Anshoru Tauhid (JAT), Majelis Mujahidin Indonesia (MMI), dan Hizbut Tahrir Indonesia (HTI). Pertanyaan penelitian yang dijawab dalam penelitian ini adalah: bagaimana konstruksi kelompok Islam fundamentalis di Indonesia terhadap pemerintah Indonesia dalam wacana (discourse) demokrasi di internet? Peneliti menjelaskan juga konteks psikologis, sosiopolitik, dan teknologi yang melahirkan wacana mereka. Tujuan penelitian ini adalah untuk memahami konstruksi kelompok Islam fundamentalis terhadap pemerintah Indonesia dalam wacana demokrasi di internet.

\section{LANDASAN KONSEP}

Demokrasi modern mencakup sepuluh komponen demokrasi, yaitu: (1) jaminan hak asasi manusia; (2) pemisahan kekuasaan dan negara hukum; (3) menerima perbedaan; (4) parlemen dan pemerintah diputuskan melalui pemilihan yang adil, bebas, dan rahasia; (5) adanya otonomi daerah dan komunitas lokal; (6) pelaksanaan pemilu; (7) kebebasan berserikat dan membentuk asosiasi; (8) adanya masyarakat sipil; (9) terciptanya ranah publik; serta (10) terciptanya budaya politik (Meyer, 2002; Dahlan, 2012; Diamond, 2006; dan UNDP dan BAPPENAS, 2009). Pendekatan untuk memahami fenomena demokrasi dapat dibagi menjadi dua, yaitu: normatif - 
maximalist dan empiris - minimalist. Pendekatan normatif - maximalist memfokuskan perhatian pada substansi demokrasi. Sebaliknya, pendekatan empirisminimalist fokus pada prosedur demokrasi, yakni pemilu (Huntington, 1996; Marquand dan Nettler, 2000; Suyatno, 2004).

Indonesia dalam membangun konsolidasi demokrasi mendapat tantangan dari kelompok fundamentalis. Kelompok ini ingin kembali kepada dasar-dasar agama secara penuh dan literal, bebas dari kompromi, penjinakan, dan reinterpretasi (Azra dalam Qohar, 2011). Mereka mengajak umat Islam kembali kepada prinsip-prinsip Islam yang fundamental, keyakinan kepada Al-Quran dan Sunnah sebagai sumber yang paling dipercaya (authoritative) bagi norma politik, ekonomi, sosial, dan kebudayaan. Fenomena ini ditemukan dalam tradisi agama Kristen, Budha, Hindu, Yahudi, dan Islam. Istilah fundamentalisme itu sendiri digunakan kali pertama oleh kaum Protestan Amerika pada awal abad ke-20 untuk membedakan diri dari protestan liberal (Suyatno, 2004).

Lahirnya fundamentalisme didorong oleh (pertama) perubahan situasi global dan masalah identitas paska perang dingin yang didominasi konflik dua aliran ideologi (Zuhri, 2011). Kedua, tata kelola pemerintah yang buruk (Javaid, 2011). Ketiga, penolakan terhadap tata nilai Barat dan sekularisasi (A'la, 2008; Ausop, 2009). Keempat, cara penafsiran dan keyakinan bahwa Islam adalah sebuah totalitas masalah kehidupan (Effendy, 2011), mencakup dîn (agama), dunyâ (dunia) dan dawlah (negara). Kelima, tekanan dan kegagalan rezim yang berkuasa (Suyatno, 2004). Keenam, obsesi kembali ke the golden ages of Islam (Zuhri, 2011). Keenam, depolitisasi dan deideologisasi umat Islam (Karman, 2015).

Karakteristik kelompok fundamentalis bersifat melawan terhadap ancaman sekularisme; menolak hermeneutics, pluralisme/relatifisme, dan persamaan gender (Harto, 2008; Misrawi dalam Nu'ad, 2005). Pembaruan masyarakat ialah dengan kembali kepada Islam berupa revolusi religio-politik dengan merujuk kepada Al-Quran dan gerakan yang dipimpin Nabi Muhammad (Esposito, 2004). Fundamentalisme ditunjukkan dengan sikap melawan kelompok yang dianggap mengancam, berjuang untuk menegakkan citacita yang mencakup persoalan hidup secara umum, berjuang dengan nilai-nilai identitas tertentu, melawan musuh-musuh dalam bentuk komunitas atau tata sosial keagamaan yang dipandang menyimpang, serta berjuang atas nama Tuhan (Taher, 1998).

Sebagai ideologi, demokrasi adalah realitas pertama yang dikonstruksi kelompok fundamentalis. Gagasan berpikir ini menuntun pada teori social construction. Teori ini mendekati komunikasi pada aspek aktivitas mendapatkan pemahaman, makna, norma, dan aturan bekerja melalui komunikasi yang intensif. Inti gagasan teori social construction adalah pengetahuan merupakan hasil dari interaksi simbolik di antara kelompok masyarakat tertentu. Realitas dikonstruksi oleh lingkungan sosial, produk dari kehidupan budaya dan kelompok (Littlejohn dan Foss, 2011). Jadi, kelompok Islam fundamentalis adalah entitas yang aktif melakukan konstruksi terhadap demokrasi. Hasil pemaknaan tersebut dieksternalisasi ke publik melalui internet. Realitas di media mereka adalah realitas psikologis yang lahir dalam konteks tertentu. Realitas psikologis ini adalah upaya membangun pemahaman mengenai dunia. Meskipun memiliki varian yang beragam, konstruksi realitas sosial memiliki asumsi yang sama: komunikasi merupakan tindakan komunikatif bersifat sukarela, produk sosial, dan selalu kontekstual (Penman dalam Littlejohn dan Foss, 2002).

\section{METODE PENELITIAN}

Paradigma penelitian ini adalah konstruktivisme. Penelitian ini mengacu kepada konstruksi kelompok Islam fundamentalis terhadap demokrasi. Cara pandang ini berguna untuk memberikan pemahaman tentang permasalahan yang sesungguhnya di dalam arena sosial (Heiner, 2006). Dari aspek ontologis, penelitian ini mengusung paham relativisme. Secara 
epistemologi, pemahaman terhadap konstruksi realitas kelompok Islam fundamentalis terhadap demokrasi merupakan produk interaksi antara peneliti dengan teks. Secara aksiologi, penelitian ini berusaha memahami gejala sosial. Secara metodologi, proses penelitian bertumpu pada proses hermeneutics dan dialektika (Guba, 1990, 1994; Crotty, 1998). Peneliti melakukan double hermeneutics, yaitu menafsirkan konstruksi kelompok Islam fundamentalis yang sejatinya merupakan tafsir mereka terhadap realitas demokrasi.

Peneliti menitikberatkan pada wacana ketiga kelompok Islam tersebut di situs mereka, yaitu: ansharuttauhid.com (JAT), majelismujahidin.com (MMI), dan situs hizbut-tahrir.or.id (HTI). Pemilihan ketiga kelompok tersebut ditentukan secara purposif berdasarkan keseragamannya agar lebih fokus dan mengurangi variasi kelompok dalam umat Islam (Patton, 2002). Dalam pencarian wacana, peneliti menggunakan kata kunci "demokrasi". Peneliti tidak menekankan waktu dan jumlah berita tapi menekankan bagaimana wacana (discourse) demokrasi tersebut itu terjadi. Begitu juga dengan jumlah berita tidak didasarkan pada kuantitasnya tapi berdasarkan muatan konstruksi mereka sehingga peneliti sampai pada tahap saturation. Pada tahap ini peneliti tidak menemukan informasi yang baru.

Keabsahan (validity) penelitian ini ditentukan oleh empat faktor: credibility (validitas internal); transferability (validitas eksternal atau generalisability); dependability (reliabilitas); confirmability (kecenderungan untuk mencapai objektivitas) (Shenton, 2004; Anney, 2014). Credibility penelitian ini dibangun dengan melakukan intertekstualitas, teks yang dianalisis dikaitkan juga dengan teks lainnya pada media lain. Teks dari situs JAT dikaitkan dengan buku akidah yang ditulis oleh tokoh JAT, misalnya, Aman Abdurahman dalam buku yang berjudul "Seri Materi Tauhid For The Gratest Happiness, Tauhid dan Jihad". Intertekstualitas untuk data situs MMI merujuk ke buku yang ditulis oleh Irfan S. Awwas (tokoh MMI) berjudul "Jejak-Jejak Jihad Kartosoewirjo". Teks dari websites HTI juga dilakukan intertekstualitas dengan bukubuku HTI yaitu "Nidzomul Islam (peraturan hidup dalam Islam), "Mafaahim Hizbut Tahrir (mengenal Hizbut Tahrir)".

Metode analisis yang digunakan adalah analisis wacana yang diperkenalkan oleh Leeuwen (2008) yang menekankan representasi tindakan sosial (social action) dan aktor sosial (social actor). Model analisis wacana tersebut berusaha mendeteksi bagaimana suatu kelompok/tindakan diposisikan.

Pemosisian sesuatu/seseorang dalam wacana didefinisikan oleh media, dalam hal ini media internet kelompok Islam fundamentalis. Model analisis wacana Leeuwen dibagi menjadi dua, yaitu strategi penghadiran (inclusion) dan strategi pengeluaran (exclusion). Ini digunakan untuk analisis representasi aktor sosial dan aksi sosial. Ia menjelaskan bahwa strategi exclusion dilakukan dengan passivation, nominalisasi, dan penggantian anak kalimat. Strategi inklusi mencakup diferensiasi-indiferensiasi, objektivitas-abstraksi, nominasi-kategorisasi, nominasi-identifikasi, determinasiindeterminasi, asimilasi-individualisasi (Leeuwen, 2008; Eriyanto, 2009).

\section{HASIL PENELITIAN DAN PEMBAHASAN}

\section{Konstruksi JAT: Pemerintah Hasil Demokrasi Kafir dan Murtad}

Menurut JAT, Muslim di negara demokrasi harus mengingkari demokrasi karena ideologi kafir. Muslim harus berupaya menggantinya dengan Islam melalui dakwah dan jihad. Jika belum mampu, maka harus melakukan i'dad (persiapan) kekuatan maksimal (Anon, 2009). Demokrasi memisahkan agama Islam dan kehidupan, mengesampingkan syariat Allah dan menyandarkan hukum kepada rakyat melalui pemilu/anggota majelis perwakilan. Demokrasi membuat vakum hukum syariah dan memadukan yang benar dengan yang salah, Islam dan kebodohan (jahiliyyah). Berdemokrasi berarti telah menurunkan 
wibawa umat Islam dan membuka pintu kemurtadan, ajaran menyimpang dengan dasar toleransi, serta membuka pintu syahwat dan sikap permisif. Berikut ini kutipannya: "Sistem demokrasi membuka lebar-lebar pintu kemurtadan dan zindiq karena di bawah naungan sistem thaghut ini memungkinkan bagi setiap pemeluk agama, madzhab atau aliran tertentu untuk membentuk sebuah partai dan menerbitkan media massa untuk menyebarkan ajaran mereka yang menyimpang dari dienullah dengan dalih toleransi dalam mengeluarkan pendapat. Sistem demokrasi membuka pintu syahwat dan sikap permisifisme...." (Anon, 2014b).

Aktor sosial pada kalimat di atas (demokrasi) secara aktif melakukan aksi yang tergolong proses behavioral yaitu "membuka" dan diperjelas dengan kata "lebar-lebar" sebagai pelengkap (circumstance of accompaniment). Ini berarti aktor sosial secara aktif melakukan perbuatan tersebut sehingga berdampak pada kemurtadan. Aktor sosial disimbolisasi secara konotatif dengan tagut (suatu objek dituhankan). Demokrasi dikonstruksi sebagai sebab perpecahan, dan mendukung program kolonialisme serta memecah dunia Islam ke dalam sukuisme, nasionalisme, dan sebagainya. Berdemokrasi menyebabkan seseorang keluar dari agama Islam, melahirkan pemimpin-pemimpin korup dan menghancurkan hukum Allah dan mengganti dengan hukum manusia.

JAT merepresentasikan diri mereka sebagai korban pemerintah. Di sisi lain, pemerintah dikonstruksi sebagai "yang mengusung agama demokrasi". Ini terlihat pada kutipan berikut ini: "Jamaah Ansharut Tauhid tidak sepi dari berbagai pressure yang dilakukan oleh pemerintah yang mengusung agama demokrasi" (Anon, 2011). Pemerintah diinklusi dengan teknik asimilasi, yaitu menghadirkan aktor sosial sebagai kelompok walaupun pelakunya individu. Kalimat yang berbunyi: "pressure yang dilakukan oleh pemerintah yang mengusung agama demokrasi" merepresentasikan pemerintah sebagai agen aktif walaupun pola kalimat di atas pasif menurut tata bahasa yang melakukan dua aksi sosial, yaitu: "melakukan pressure" dan "mengusung agama demokrasi". Frase "agama demokrasi" menunjukkan konstruksi JAT dalam melihat orang lain yang berbeda dalam memaknai demokrasi. Pemerintah disebut "thaghut" dan "konsorsium setan".

Pemerintah Indonesia dipastikan tidak akan membawa kepada keadilan karena undang-undang yang dibuat oleh penguasa zalim. Ini dipertegas dengan kalimat "tidak ada satu manusia pun, walaupun kafir", dan dengan kata "pasti", "tidak akan pernah berpihak pada keadilan". Ini bermakna menutup semua kemungkinan bahwa pemerintah Indonesia yang berdemokrasi itu bisa memberikan kebaikan dan keadilan bagi masyarakat (Anon, 2014g). Pemerintah digelari (pseudo title) dengan frase "penguasa zalim", "yang memiliki tangan kotor", dan "penguasa yang menyombongkan diri", serta label buruk: "munafik", "hedonis", "sombong", dan "dusta". JAT bahkan mengatakan, pegawai yang bekerja pada sistem pemerintah yang tidak menerapkan sistem Islam (PNS, TNI/POLRI, dan lain-lain) berstatus murtad. Berikut kutipannya: "Orang Islam yang rela menjadi pegawai di dalam negara kafir adalah murtad, selama mereka ber-wala' (loyal) kepada kepala negara tersebut (thaghut), tidak mengafirkan, tidak membenci, dan tidak melawan thaghut tersebut bahkan justru mereka membela dan melindunginya" (Anon, 2014f).

PNS dikatakan kafir karena harus menyatakan ikrar atau janji setia kepada Pancasila dan UUD 1945, sistem thaghut, dan Negara Kafir Republik Indonesia. Sebaliknya, JAT mendukung ISIS (Islamic State of Iraq and Syria) dan mengakuinya sebagai khilafah.

\section{Konstruksi MMI: Pemerintah Sebagai Fir'aun}

MMI menghendaki pelaksanaan syariah Islam secara menyeluruh (kaffah). Konsekuensinya, ia menolak sistem demokrasi dalam kehidupan bernegara karena sistem demokrasi itu sekuler. Berdemokrasi berarti ketidaksempurnaan dalam menaati Allah dan bentuk kesyirikan. Pandangan kelompok fundamentalis terhadap pemerintah merefleksikan pandangan mereka terhadap 
demokrasi secara keseluruhan. Menurutnya, demokrasi hanyalah melahirkan firaun-firaun kecil, yang menjerumuskan rakyat ke neraka.

Awwas menyatakan doa, harapan, dan ikhtiar rakyat Indonesia belum juga terwujud. Pilpres setiap lima tahun sekali, sampai sekarang ternyata hanya utopia. Presiden terpilih yang datang silih berganti tidak dapat menjalankan amanah konstitusi, gagal memenuhi cita-cita kemerdekaan. Mereka justru menjadi firaun-firaun kecil yang menjerumuskan rakyatnya ke jalan neraka (Awwas, 2014).

Aktor sosial pada kalimat di atas dihadirkan (inclusion) dengan postmodification. Kata benda (noun) "doa", "harapan", dan "ikhtiar" diaktivasi dengan kata "Rakyat Indonesia". Rakyat Indonesia yang direpresentasikan secara umum (genericization) memberikan efek melebihlebihkan (glorification) terhadap (re)aksi, yaitu: berdoa (aksi verbal process), berharap (reaksi mental process), berikhtiar (aksi behavioral process). Aksi sosial pada kata "terwujud" meniadakan agen sosialnya. Siapa orang yang mewujudkan doa, harapan, dan ikhtiar rakyat Indonesia dihilangkan (backgrounded).

Kalimat "pilpres setiap lima tahun sekali, sampai sekarang ternyata hanya utopia" merepresentasikan aksi sosial berupa aktivitas memilih presiden dengan cara deactivating, yaitu mengganti kata kerja "memilih" dengan "pemilihan". Cara ini dikenal dengan objectivated action. Deactivating pada kalimat ini juga dengan cara metonym, yaitu dengan frase "sampai sekarang" yang memberikan makna proses yang berjalan lama. Kata "ternyata" yang digunakan pada kalimat di atas menunjukkan bentuk deagentialisasi yang menggambarkan reaksi bukan sebagai akibat perbuatan manusia. Caranya adalah dengan existentialization, sesuatu itu terjadi begitu saja, dengan sendirinya sehingga tidak mendorong pembaca bertanya: "siapa yang membuat nyata?".

Kata "presiden" didelegitimasi dengan cara aktivasi bahwa presiden "tidak dapat menjalankan amanah konstitusi", dan "gagal memenuhi cita-cita kemerdekaan".
Pemerintah justru disimbolkan dengan Firaun. Delegitimasi pemerintah ditunjukkan juga dengan kalimat "yang menjerumuskan rakyatnya ke jalan neraka". Firaun merupakan jelmaan dari penguasa dan penindas yang didukung para loyalis dan birokrasi kekuasaan. Selain mendelegitimasi pemerintah, MMI menyalahkan rakyat karena berperan dalam pemilu yang melahirkan firaun. Lahirnya pejabat-pejabat yang rakus, tidak bermoral, mati rasa, kesat hati, dan yang menjerumuskan rakyat ke lembah nista dan teraniaya merupakan tanggung jawab rakyat yang telah memilihnya. Dosa terbesar justru ditanggung oleh rakyat karena pemimpin durjana seperti itu lahir dari pilihan langsung oleh rakyat atas nama demokrasi.

Awwas menyebutkan lahirnya pemimpin yang tidak becus mengurus negara, pejabat-pejabat yang rakus, tidak bermoral, mati rasa dan kesat hati, menjerumuskan rakyatnya ke lembah nista dan teraniaya, merupakan tanggung jawab rakyat yang memilihnya. Dosa terbesar justru ditanggung oleh rakyat karena pemimpin durjana seperti itu lahir dari pilihan langsung oleh rakyat atas nama demokrasi (Awwas, 2011).

Pernyataan di atas merepresentasikan pemimpin hasil demokrasi dengan pemberian kata sifat "tidak becus", "rakus", "tidak bermoral", "mati rasa", dan "kesat hati". Pemimpin juga direpresentasikan dengan pasifikasi dengan anak kalimat "menjerumuskan rakyatnya ke lembah nista dan teraniaya". Wacana ini memberikan efek yang disebut dengan overdetermination. Sementara itu, rakyat direpresentasikan secara umum harus menanggung dosa karena ikut melahirkan pemimpin yang disifati dengan "durjana". Makna keseluruhan adalah MMI mendelegitmasi pemerintah sekaligus mendiskreditkan rakyat yang ikut dalam proses pemilu. Sebagai bagian dari demokrasi, pemilu merupakan bagian dari kesyirikan.

\section{Konstruksi HTI: Pemerintah Sebagai Antek Penjajah}

HTI menciptakan wacana perlawanan terhadap agenda politik pemerintah (pemilu). Sementara pemerintah mendorong masyarakat 
berpartisipasi dalam demokrasi, HTI mengajak masyarakat mencampakkan demokrasi dan memerjuangkan Khilafah Islamiyah. Menurutnya, demokrasi dari "company, oleh company, dan untuk company". Sukses tidaknya seseorang dalam pemilu ditentukan dana dan pencitraan. Keterlibatan company selalu ada dalam bentuk pemberian dukungan kepada partai politik dari sisi finansial. Akibatnya, kebijakan yang lahir berorientasi pada kepentingan elit politik dan pemilik modal (Anon, 2014d).

Demokrasi terbukti gagal dalam menyejahterakan rakyat. Ia membentuk simbiosis mutualisme/perselingkuhan antara elit politik dan pemilik modal yang merugikan rakyat. Dalam demokrasi, kepentingan ekonomi dan politik senantiasa beriringan. Demokrasi dinilai bertentangan dengan Islam karena menggantikan peran Allah sebagai pembuat hukum. Jadi, demokrasi haram diadopsi, dipraktikkan dan disebarluaskan. Ia adalah thaghut. Sikap ini tergambar dalam kutipan berikut ini: "Demokrasi, baik secara istilah maupun makna, adalah sistem kufur yang haram untuk diadopsi, dipraktikkan dan disebarluaskan. Demokrasi adalah thaghut yang harus dienyahkan. Tidak ada islamisasi demokrasi. Islamisasi demokrasi sama artinya menyetarakan keimanan dengan kekufuran, atau memaksakan agar kekufuran menjadi bagian dari ajaran Islam” (Anon, 2014e).

Wacana HTI tersebut mendelegitimasi demokrasi itu dari sisi istilah dan makna. Delegitimasi ini berpijak pada landasan doktrin agama seperti tampak dari jargon yang dipakai, yaitu: "kufur", "haram", dan "thaghut". Kata "demokrasi" pada awal kalimat pada paragraf di atas secara tata bahasa menjadi subjek dalam pola kalimat pasif. Pelakunya dihilangkan dalam struktur kalimat dengan cara backgrounded, yaitu melenyapkan aktor sosial secara tidak radikal sehingga pembaca bisa menelisik siapa aktor sebenarnya dengan melihat pada kalimat lain. Pelenyapan aktor sosial ini menguntungkan wacana HTI. Kesan yang terbangun dari kalimat di atas adalah status haram dan kufurnya demokrasi itu bukan hanya pendapat pihak tertentu saja (masalah khilafiyahijtihadiyyah), tetapi menurut Islam.

Frase "sistem kufur" tersebut dipertegas lagi dengan anak kalimat "...yang haram untuk diadopsi, dipraktikkan dan disebarluaskan". Penyifatan pada "sistem kufur" ini merupakan cara melenyapkan aktor sosial. Sebab, pelaku sosial yang mengadopsi, memraktikkan, menyebarluaskan tidak dihadirkan dalam teks. Demokrasi direpresentasikan sebagai thaghut. Simbolisasi demokrasi dengan thaghut adalah strategi overdeterminasi untuk memberikan efek kuat akan bahaya demokrasi. Kalimat "tidak ada islamisasi demokrasi..." menunjukkan pandangan HTI yang berusaha membantah pandangan kelompok Islam lain yang menerima demokrasi. Islamisasi demokrasi sama artinya dengan memaksakan thaghut menjadi sesembahan orang-orang beriman. Ekspresi penolakan demokrasi selain dengan frase "sistem kufur" juga diungkapkan dengan kata "najis, dan menggiring umat Islam ke dalam perbuatan syirik (penyekutuan Allah).

Demokrasi telah menggiring umat Islam kepada kesyirikan. Telah jelas bahwa dalam demokrasi, manusia secara angkuh dan sombong berani menjadi pesaing Allah SWT dalam hal membuat aturan untuk kehidupan manusia (Anon, 2014c).

Wacana di atas menunjukkan, delegitimasi terhadap demokrasi dengan argumen teologis, dengan jargon-jargon agama. Aktor sosial ("demokrasi") direpresentasikan melakukan aksi sosial ("membawa"). Kata ini menunjukkan aksi berupa proses behavioral yang memberikan legitimasi reaksi HTI yang muncul kemudian. Mereka yang terlibat dalam proses demokrasi tergolong manusia yang angkuh, sombong, serta berani menjadi pesaing Allah. Penggunaan kata "menjadi" dalam kalimat ini menunjukkan bahwa proses aktor menjadi orang yang angkuh, sombong itu berjalan secara alamiah (eventuation).

Demokrasi sebagai aktor sosial dihadirkan melakukan aksi "membikin dosa". Kata "membikin" ini menunjukkan proses material yang berarti bahwa aktivitas ini 
bersifat aksi. Demokrasi juga melakukan aksi yaitu "membawa" ke dalam "jurang kesengsaraan". Penggunaan kata "jurang" ini memberikan efek overdeterminasi besarnya kesengsaraan. Konsekuensi logis penolakan demokrasi, HTI mendelegitimasi dan mendemoralisasi pemerintah terpilih hasil Pemilu 9 Juli 2014 (Joko Widodo dan Jusuf Kalla) sebagai presiden dan wakil presiden periode 2014-2019. Mereka dianggap sebagai antek penjajah. Sikap merakyat mereka dianggap sebagai kepura-puraan (Anon, 2014a).

Temuan di atas membuktikan bahwa internet digunakan oleh kelompok Islam fundamentalis untuk mendiseminasikan wacana yang bukan hanya berbeda tapi mengandung perlawanan terhadap pemerintah atau subversi-politik. Subbab ini akan mendiskusikan temuan tersebut di atas dengan melihat konteks lahirnya subversi kelompok fundamentalis di Indonesia dan mendiskusikannya juga dari sudut pandang budaya teknologi yang berpengaruh dalam perubahan sosio-politik.

\section{Memahami Konteks Sosial Politik Lahirnya Wacana Subversi}

Wacana penolakan demokrasi sebagai hasil konstruksi kelompok fundamentalis dipengaruhi oleh konteks sosial, politik, dan psikologis mereka. Konstruksi mereka terhadap demokrasi dipengaruhi oleh dinamika internal (psikologis) dan dinamika eksternal (kondisi social - politik baik nasional maupun global). Pertama, dinamika internal (konteks psikologis). Sikap kelompok fundamentalis dipengaruhi oleh doktrin fiqh atau validitas teologis, yaitu tentang kesempurnaan Islam yang mencakup bukan hanya persoalan agama, tapi juga persoalan dunia (politik, ekonomi, sistem pengadilan, perdagangan, diplomasi, dan lain-lain), dan persoalan negara yang menjadi puncak perjuangan kelompok fundamentalis. Format negara Islam itu sendiri berbeda-beda di kalangan mereka. HTI menginginkan terbentuknya Khilafah Islamiyah yang menerabas batas negara bangsa (nation state).
MMI menghendaki formalisasi syariah Islam di wilayah Indonesia dengan inspirasi dari model Negara Islam Indonesia yang didirikan oleh S.M. Kartosoewirjo. JAT mengakui ISIS sebagai khilafah. Di Indonesia, selain berpijak pada validitas teologis tadi, kelompok Islam fundamentalis berpijak pada klaim validitas historis bahwa mereka merasa paling berjasa terhadap Indonesia. Umat Islam paling berperan terhadap Indonesia sebelum kemerdekaan. Peran yang dimaksud adalah membentuk civic culture berupa kerajaan yang berdiri pada abad ke-13 yang dipengaruhi oleh tata negara Islam, bukan hinduisme. Peran umat Islam yang lain adalah pembentuk solidaritas nasional dan syariah jihad yang menjadi motivator satu-satunya untuk meraih kemerdekaan dan kontrol sosial di NKRI. Kelompok fundamentalis terobsesi untuk mengembalikan tatanan hidup ideal seperti pada masa Rasulullah. Jadi, ada dinamika psikologis dalam bentuk romantisme kembali ke masa kejayaan (golden age). Dinamika internal ini merupakan pra pemahaman (episteme/habitus) mereka yang memengaruhi bagaimana konstruksi mereka terhadap demokrasi.

Kedua, dinamika eksternal. Kelompok fundamentalis di Indonesia dipengaruhi oleh kondisi sosiopolitik juga memengaruhi konstruksi mereka terhadap demokrasi. Pada Orde Baru, peran umat Islam mengalami deideologisasi dan depolitisasi. Umat Islam mendapat kekangan dari aparat represif negara (militer). Ini terlihat pada peristiwa daerah operasional militer di Aceh pada 1989-1998, peristiwa Tanjung Priok (1984). Umat Islam juga dipantau oleh aparat ideologi negara (intelijen). Aparat intelijen pada masa Orde Baru adalah Badan Intelijen Strategis/BAIS yang berasal dari unsur tentara. Badan koordinator intelijen negara yang diisi oleh orang sipil, institusi pendidikan seperti Lembaga Sandi Negara, dan jaksa muda bidang intelijen. Badan yang menyentuh sampai tingkat desa adalah BAIS, Direktorat Jenderal Sosial Politik, dan Kopkamtib (Komando Keamanan dan Ketertiban) yang kemudian berubah menjadi Bakorstanas (Badan Koordinasi Strategi Nasional). 
Dinamika eksternal kelompok Islam fundamentalis dipengaruhi juga kondisi geopolitik dengan jatuhnya Turki Utsmani oleh Kemal Ataturk tahun 1924 yang disusul gerakan westernisasi. Dinamika internal dan eksternal tadi kemudian mengerucut menjadi konstruksi mereka terhadap demokrasi sebagai ideologi dan sebagai sistem yang tidak berasal dari Islam tapi dari Barat.

$\begin{array}{rrrr}\text { Paska } & \text { reformasi } & 1998 & \text { menjadi } \\ \text { momentum } & \text { untuk } & \text { eksternalisasi }\end{array}$
gagasan/pemikiran mereka. Media (cetak, radio, televisi) sebagai channel terbuka lebar tanpa kekangan dan kungkungan penguasa seiring dengan kebebasan berekspresi. Liberalisasi saluran komunikasi kian pesat dengan munculnya internet dan pembangunan infrastruktur teknologi informasi dan komunikasi lainnya. Karakteristik internet yang efesien menarik kelompok fundamentalis untuk memanfaatkannya sebagai saluran untuk menyebarkan wacana subversi politik terhadap penguasa.

\section{Memahami Penggunaan Kelompok Islam Fundamentalis}

Internet

Gerakan perlawanan/revolusi (people power) terhadap penguasa selalu menggunakan media terkini pada masanya. Revolusi di Filipina tahun 1986 menggunakan mobile-handy talkie, revolusi kelompok menengah di Thailand tahun 1992 menggunakan teknologi telepon genggam untuk menghindari pengawasan aparat keamanan, aktivis gerakan reformasi 1998 juga menggunakan komunikasi telepon genggam untuk mengoordinasikan aksi mereka. "Revolusi SMS" pernah terjadi di Filipina tahun 2001. SMS berhasil mengoordinasikan 700.000 demonstran dan berhasil menggulingkan Joseph Estrada. Bukti nyata kehebatan teknologi komunikasi adalah ditemukannya teknologi movable-type printing press technology oleh Johannes Gutenberg 1440 atas permintaan Martin Luther King. Dengan teknologi itu, Bible (Biblia Sacra) dapat disebarkan dan dimiliki setiap individu sehingga tidak ada monopoli tafsir kebenaran dari pihak gereja atas firman Tuhan. Temuan Gutenberg tersebut bahkan memainkan peran kunci dalam mengantarkan masyarakat Eropa memasuki era pencerahan (enlightenment), renaissance, revolusi ilmu pengetahuan (scientific revolution), serta meletakkan dasar bagi lahirnya knowledgebased economy. Revolusi Mesir dan Musim Semi Arab (Arabic Spring) juga diduga karena teknologi internet (Dahlan, 2012; McLuhan, 1962).

Sebagai media, internet adalah jaringan elektronik yang menghubungkan orang dan informasi melalui komputer dan teknologi media digital lainnya, yang memungkinkan terjadinya komunikasi antarpribadi dan pencarian informasi (Mirabito dan Morgenstern, 2004; Flew, 2005). Internet mampu menghilangkan hambatan geografis dan waktu. Perubahan budaya teknologi ini memberikan peluang bagi kelompok fundamentalis untuk menjadikannya sebagai sarana menyebarkan gagasan atau pemikirannya. Apalagi potensi penggunaan internet tumbuh pesat seperti yang dibuktikan dalam beberapa laporan penelitian, seperti penelitian oleh Irwansyah (2011), Kementerian Komunikasi dan Informatika, (2012), Masyarakat Telematika (MASTEL) (2012), Buku Putih Kementerian Komunikasi dan Informatika (2013), dan Asosiasi Penyelenggara Jasa Internet Indonesia (2014).

Dengan demikian, pesan-pesan subversi dapat menyebar secara luas melampaui batas geografis. Ini karena internet ini bisa memicu lahirnya cyberspace, virtual world, network society (Metzger, 2009). Internet bersifat integratif, interaktif, dan kode digital pada proses penyimpanan, pengiriman, dan penerimaan informasi (Dijk, 2006; Flew, 2005; McQuail, 2010; Tomasselo, 2010). Karena digitalisasi, informasinya bersifat manipulable, networkable, dense, compressible, impartial (Flew, 2005).

Potensi internet yang digunakan kelompok Islam fundamentalis menjadi tantangan bagi pemerintah. Membangun sarana internet di satu sisi menjadi enabling factor untuk perbaikan sistem ekonomi, perdagangan, dan pendidikan. Di tangan kelompok fundamentalis, internet justru digunakan untuk memosisikan pemerintah 
pada posisi yang sulit. Pemerintah kesulitan menghadapi konten berisi wacana subversi, radikal yang lahir melalui internet. Interkonektivitas internet menjadikan informasi melampaui batas geografis. Pidato anti-pemerintah yang disampaikan tokoh Hizbut Tahrir di luar negeri bisa disebarkan oleh Hizbut Tahrir Indonesia melalui situsnya. Abu Bakar Ba'asyir (tokoh JAT) walaupun ditahan di Nusakambangan ia dapat mengamati situasi politik di Timur Tengah secara real time dan memberikan dukungan kepada ISIS yang kemudian ini menjadi sikap resmi organisasi JAT.

Kontrol terhadap wacana subversi tidak bisa dengan penghapusan konten yang mengandung kata kunci tertentu seperti dalam penanganan konten pornografi. Begitu juga kontrol konten subversi dengan melakukan pemblokiran situs-situs yang direkomendasikan BNPT kepada Kementerian Kominfo bukanlah cara yang efektif bahkan terbukti kontraproduktif berupa reaksi penolakan dari segmen umat Islam. Ketidakefektifan disebabkan (pertama) bila situs kelompok fundamentalis diblok, mereka dengan mudahnya memindahkan konten radikalnya ke domain, internet protocoladdress yang berbeda sehingga lepas dari daftar situs dilarang. Kedua, pemblokiran menempatkan pemerintah pada posisi dilematis karena pemblokiran itu tidak sejalan dengan substansi demokrasi yang dibangun pemerintah itu sendiri seperti freedom of expression, dan ruang publik internet.

Protes masyarakat terhadap Kementerian Kominfo juga disebabkan pemblokiran situs Islam bermuatan radikal tidak didasari peta gerakan Islam, kelompok Islam mana yang 'jinak' dan yang bisa diajak dialog dan mana yang tidak bisa. Hasil penelitian ini menunjukkan bahwa walaupun dalam nomenklatur yang sama, kelompok Islam fundamentalis memiliki varian dan sikap yang berbeda-beda terhadap demokrasi. Oleh karena itu, penanganan kelompok Islam fundamentalis harus berbeda pula. Ada kelompok fundamentalis yang membuka ruang diskusi, dialog seperti HTI. Ada juga kelompok fundamentalis seperti JAT yang menutup ruang dialog dengan pemerintah karena pemerintah direpresentasikan sebagai orang kafir dan murtad.

HTI walaupun berkeinginan mendirikan Khilafah Islamiyah, namun tetap mematuhi hukum di Indonesia misalnya sebagai ormas, HTI mendaftarkan diri ke Kementerian Hukum dan Hak Asasi Manusia. Organisasi tersebut juga melibatkan pihak pemerintah dalam acaranya (seminar/dauroh peradaban). Kebebasan berekspresi dalam alam demokrasi public sphere di internet dijadikan sarana diseminasi ide. HTI melibatkan diri dalam dialog, pergulatan pemikiran (ghozwul fiqri) dengan pemikiran/ideologi lain termasuk demokrasi, kapitalisme. Namun, HTI tidak melakukan konfrontasi terhadap Pancasila.

Sementara itu, JAT membangun benteng demarkasi yang memisahkannya dengan pemerintah yang dianggap beragama demokrasi. MMI menyiasati demokrasi dengan memperjuangkan ide Islam dalam menafsirkan konstitusi Republik Indonesia sebagai usaha formalisasi syariah Islam di Indonesia. Berbeda dengan HTI dan MMI yang mengatakan demokrasi sebagai sistem kufur, JAT mengataan bahwa pemerintah Indonesia kafir dan murtad. Secara teologis pernyataan tersebut memberikan konsekuensi yang jauh berbeda ketika mengatakan pemerintah sebagai kafir dan murtad dengan pernyataan demokrasi itu sistem kufur. Bahayanya adalah ini bisa dijadikan dasar untuk tindakan yang tidak berprikemanusiaan seperti pembunuhan. Ini terlihat pada pembelaan JAT terhadap tiga pelaku bom Bali tahun 2002 (Ali Ghufron/Mukhlas, Amrozi, dan Imam Samudra).

\section{PENUTUP}

\section{Simpulan}

Kelompok Islam fundamentalis mendekonstruksi demokrasi dari pendekatan teologis dan dampak buruk sosial ekonomis. Secara teologis, kelompok Islam fundamentalis menolak demokrasi karena ia adalah bagian dari sistem kufur, batil, sesat, dan najis. Kelompok fundamentalis radikal 
(JAT) bahkan mengatakan demokrasi itu adalah agama sendiri. Konsekuensinya, berdemokrasi berarti keluar dari Islam, menjadi kafir dan murtad. Kelompok fundamentalis menyalahkan rakyat karena ikut serta dalam pemilu yang melahirkan pemimpin yang tidak bermoral dan birokrasi korup. Kelompok fundamentalis mendelegitimasi dan mendemoralisasi demokrasi sebagai sistem korporatokratis dan menciptakan simbiosis mutualisme antara penguasa dan pengusaha. Demokrasi alat kepentingan Barat sehingga presiden yang terpilih adalah antek penjajah.

Kelompok

fundamentalis merepresentasikan pemerintah sebagai "thaghut", "sesembahan", "setan" karena menerima demokrasi yang berarti pemerintah membuka pintu syahwat dan permisifisme, membuka pintu perpecahan dan perselisihan, mendukung program-program kolonialisme, memecah-belah dunia Islam ke dalam nasionalisme, negara-negara kecil (nation state), serta memadukan haq (kebenaran) dan bathil (kejahatan). Pemerintah dikonstruksi sebagai firaun yang menerapkan sistem atau paham firaun dalam birokrasi. Konstruksi mengenai haramnya demokrasi untuk diadopsi dan diadaptasi bermuara pada kesimpulan bahwa haramnya demokrasi tersebut bukanlah persoalan perbedaan pendapat atau ijtihadiyyah/khilafiyah, tapi menurut Islam.

Penggunaan teknologi internet bagi kelompok fundamentalis memberikan tantangan bagi pemerintah dan demokrasi yang menjadi doxa/grand narrative saat ini. Kelompok fundamentalis tidak hanya menghadirkan narasi kecil (petite narrative) yang berbeda (distinction) tapi mengandung unsur subversi/perlawanan terhadap pemerintah. Internet menjadi faktor pemungkin subversi tersebut. Namun, internet sebagai media tidak menjadi determinan utama lahirnya subversi itu sendiri. Ada faktor psikologis (seperti validitas teologis dan historis) serta faktor sosial-politik baik nasional maupun global. Internet hanyalah extension dari kepentingan mereka.

\section{Saran}

Saran Akademik. Untuk kajian selanjutnya (further researches), hasil penelitian ini bisa dijadikan kajian awal untuk melihat gejala sosial ini secara lebih mendalam, dengan pendekatan atau paradigma yang berbeda untuk melengkapi keterbatasan dalam penelitian ini. Studi selanjutnya bisa mengkaji fenomena fundamentalisme ini dari sisi pengalaman mereka (fenomenology), konstruksionisme mereka, atau bagaimana jaringan kelompok fundamentalis ini terbentuk dalam jaringan global, bagaimana tingkat kekuatan mereka mampu merubah struktur yang ada dengan mengkaji pada elemen kapital mereka (ekonomi, budaya, simbolik, dan sosial).

Saran Praktis. Pemerintah (BNPT dan Kementerian Kominfo) secara proaktif perlu merumuskan formula tepat bagaimana mengawasi konten radikal sehingga tidak kontraproduktif dan menciptakan efek bumerang. Pemerintah perlu membuat klasifikasi organisasi-organisasi Islam dan situs-situs mereka. Hasil kategorisasi tersebut dijadikan referensi aksi pemerintah selanjutnya. Di saat yang bersamaan, konten positif dan literasi masyarakat perlu ditingkatkan pada aspek kualitas dan kuantitas. Masyarakat tidak sepatutnya bersikap stigmatis bahwa semua kelompok Islam radikal atau berpotensi seperti mereka hanya melihat adanya kesamaan pada sisi tertentu misalnya tampilan fisik. Penelitian menunjukkan bahwa kelompok fundamentalis terbukti berbeda satu sama lain.

\section{DAFTAR PUSTAKA}

A'la, A. (2008). Genealogi Radikalisme Muslim Nusantara. Akar dan Karakteristik Pemikiran dan Gerakan Kaum Padri dalam Perspektif Hubungan Agama dan Politik Kekuasaan. Surabaya: IAIN Sunan Ampel. [Online]. Available at: http://eprints.uinsby.ac.id/13/1/abd a'la.pdf.

Anney, V. N. V. (2014). Ensuring the quality of the findings of qualitative research: looking at Trustworthiness Criteria. Journal of Emerging Trends in Educational Research 
and Policy Studies (JETERAPS), 5 (2), p.272-281. [Online]. Available at: http://jeteraps.scholarlinkresearch.com/artic les/Ensuring the Quality of the Findings of Qualitative Research NEW.pdf [Accessed: 1 June 2016].

Anon. (2009). Sikap JAT tentang Demokrasi. [Online]. Available at: ansharuttauhid.com [Accessed: 29 December 2014].

Anon. (2011). JAT Siap Hadapi Isu Pembubaran! [Online]. Available at: ansharuttauhid.com [Accessed: 29 December 2014].

Anon. (2014a). "Selama Menerapkan DemokrasiKapitalisme Liberal Jokowi-JK Tetap Antek Penjajah!". [Online]. Available at: http://hizbut-

tahrir.or.id/2014/10/29/selama-

menerapkan-demokrasi-kapitalisme-liberaljokowi-jk-tetap-antek-penjajah/ [Accessed: 6 January 2015].

Anon. (2014b). Dampak Kerusakan Demokrasi. [Online]. Available at: ansharuttauhid.com [Accessed: 29 December 2014].

Anon. (2014c). HIP Kendal: Harapan Semu Demokrasi. [Online]. Available at: http://hizbut-tahrir.or.id/2014/05/08/hipkendal-harapan-semu-demokrasi/ [Accessed: 28 December 2014].

Anon. (2014d). HTI Banjarbaru: Demokrasi Sistem Rusak, Menghasilkan Kerusakan. [Online]. Available at: http://hizbuttahrir.or.id/2014/04/21/hti-banjarbarudemokrasi-sistem-rusak-menghasilkankerusakan/ [Accessed: 27 January 2015].

Anon. (2014e). Pemilu, Sulap Demokrasi Kelabui Rakyat. [Online]. Available at: http://hizbuttahrir.or.id/2014/04/23/pemilu-sulapdemokrasi-kelabui-rakyat/ [Accessed: 28 December 2014].

Anon. (2014f). Pernyataan Sikap JAT Terhadap Umat Islam Yang Menolak Khilafah Islamiyyah. [Online]. Available at: ansharuttauhid.com [Accessed: 29 December 2014].

Anon. (2014g). Siapakah yang Lebih Baik Dinnya? [Online]. Available at: ansharuttauhid.com [Accessed: 29 December 2014].

Asosiasi Penyelenggara Jasa Internet Indonesia. (2014). Indonesia Internet Users. [Online]. Available at: http://www.apjii.or.id [Accessed: 28 April 2014].

Ausop, A. Z. (2009). Demokrasi dan Musyawarah Dalam Pandangan Darul Arqam, NII, dan
Hizbut Tahrir Indonesia. Jurnal Sosioteknologi, 8 (17), p.601-620.

Awwas, I. S. (2011). Melawan Kerakusan Penguasa. p.Situs Resmi Majelis Mujahidin. [Online]. Available at: http://www.majelismujahidin.com/2011/01/ melawan-kerakusan-penguasa/ [Accessed: 18 December 2014].

Awwas, I. S. (2014). Tausiyah: Solusi Memilih Pemimpin. p.Situs Resmi Majelis Mujahidin. [Online]. Available at: http://www.majelismujahidin.com/2014/04/ tausiyah-solusi-memilih-pemimpin/ [Accessed: 18 December 2014].

Crotty, M. (1998). The Foundations of Social Research. Meaning and Perspective in the Research Process. St. Leonards: Allen \& Unwin.

Dahlan, M. A. (2012). New Media and Islam: Communication characteristics and Dynamics. Journal Communication Spectrum, 1 (2). [Online]. Available at: http://jurnal.bakrie.ac.id/index.php/Journal_ Communication_spectrum/article/view/35.

Dallmayr, F. (2011). Whither democracy? Religion, politics and Islam. Philosophy \& Social Criticism, 37 (4), p.437-448. [Online]. Available at: doi:10.1177/0191453710397927.

Diamond, L. (2006). Electoral System and Democracy. Marryland: The John Hopkin.

Dijk, J. Van. (2006). The Network Society: Social Aspects of New Media. 2nd ed. London, Thousand Oaks-CA, New Delhi: Sage Publications, Inc.

Effendy, B. (2011). Islam dan Negara: Transformasi Gagasan dan Praktik Politik Islam di Indonesia. Jakarta: Democracy Project Yayasan Abad Demokrasi.

Eriyanto. (2009). Analisis Wacana, Pengantara Analisis Teks Media. Yogyakarta: LKIS.

Esposito, J. L. (2004). ISLAM: The Straight Path. 3rd Editio. London: University Press, Inc.

Flew, T. (2005). New Media, and Introduction. 2nd editio. UK: Oxford University Press.

Gaffar, A. (1996). Politik Indonesia Menuju Transisi Demokrasi. Jakarta: Pustaka Pelajar.

Guba, E. G. (1990). The Paradigm Dialog. Newbury Park, London, New Delhi: Sage Publications, Inc.

Guba, E. G. (1994). Competing Paradigms In Qualitative Research. In: Denzin, N. K. and Lincoln, Y. S. (eds.), Handbook of Qualitative Research, London, Thousand 
Oaks-CA, New Delhi: Sage Publications, Inc.

Haqqani, H. (2013). Islamists and Democracy: Cautions from Pakistan. Journal of Democracy, 24 (2), The Johns Hopkins University Press, p.5-14. [Online]. Available at: doi:10.1353/jod.2013.0029.

Harto, K. (2008). Islam Fundamentalis di Perguruan Tinggi Umum, Kasus Gerakan Keagamaan Mahasiswa Universitas Sriwijaya Palembang. Jakarta: Badan Litbang dan Diklat Departemen Agama.

Hefner, R. W. (2001). Civil Islam: Islam dan Demokrasi di Indonesia. Jakarta: ISAI.

Heiner, R. (2006). Social Problems: An Introduction To Critical Constructionism. 2nd ed. New York: Oxford University Press.

Huntington, S. P. (1996). Gelombang Demokratisasi Ketiga (Terj. Asril Marjohan). Jakarta: PT. Pustaka Utama Grafiti.

Irwansyah. (2011). Teknologi Komunikasi Sebagai Ekstensi Kekerabatan-Studi Analisis Jaringan Sosial Kekerabatan Berbasis Teknologi Komunikasi Telephone Seluler. Universitas Indonesia.

Javaid, U. (2011). Thriving Fundamentalism and Militancy in Pakistan: An Analytical Overview of their Impact on the Society. South Asian Studies A Research Journal of South Asian Studies, 26 (1), p.9-18.

Karman. (2015). Konstruksi Nilai-Nilai Demokrasi Kelompok Islam Fundamentalis di Media Online. PEKOMMAS, 18 (3), p.181-190.

Kementerian Komunikasi dan Informatika. (2012). Pola Penggunaan Media Digital di Kalangan Anak dan Remaja. Jakarta.

Kementerian Komunikasi dan Informatika. (2013). Komunikasi dan Informatika Buku Putih 2013. Jakarta.

Leeuwen, T. Van. (2008). Discourse and Practice: New Tools For Critical Discourse Analysis. New York: Oxford University Press, Inc.

Lestari, N. (2014). Wacana Demokrasi dalam Public Sphere Komunikasi Politik di Organisasi Islam Indonesia (Analisis Wacana Demokrasi di HTI, FPI, Muhammadiyah, dan NU). Universitas Indonesia.

Liddle, R. W. (1997). Islam, Politik, dan Modernisme. 1st ed. Jakarta: Pustaka Sinar Harapan.
Littlejohn, S. W. and Foss, K. A. (2002). Theories of Human Communication. 7th ed. Belmont, CA: Thomson Wadsworth.

Littlejohn, S. W. and Foss, K. A. (2011). Theories of Human Communication. 10th ed. Long Grove, lllinois: Waveland Press, Inc.

Marquand, D. and Nettler, R. L. (2000). Religion and Democracy. Oxford: Blackwell Publisher.

Masyarakat Telematika (MASTEL). (2012). ICT Outlook. Jakarta.

McLuhan, M. (1962). The Gutenberg Galaxy: The Making of Typographic Man. 1st ed. Canada: University of Toronto Press.

McQuail, D. (2010). McQuail's Mass Communication Theory. 6th ed. Thousand Oaks, CA: Sage Publications, Ltd.

Metzger, M. J. (2009). The Study of Media Effects In The Era of Internet Communication. In: Nabi, R. L. and Oliver, M. B. (eds.), The SAGE Handbook of Media Processes and Effects, London, Thousand Oaks-CA, New Delhi: Sage Publications, Inc.

Meyer, T. (2002). Demokrasi: Sebuah Pengantar Untuk Penerapan. Jakarta: D'print Communication.

Mirabito, M. M. A. and Morgenstern, B. L. (2004). The New Communications Technologies: Applications, Policy, and Impact. 5th ed. Oxford, UK: Elsevier, Inc.

Muhtadi, B. (2009). The Quest for Hizbut Tahrir in Indonesia. Asian Journal of Social Science, 37 (4), Brill, p.623-645. [Online]. Available at: doi:10.1163/156853109X460219 [Accessed: 8 June 2016].

Mujani, S. (2007). Muslim Demokrat. Jakarta: Gramedia Pustaka Utama.

Muthohirin, N. (2014). Mahasiswa di Pusaran Fundamentalisme Islam, Studi Kasus di Universitas Indonesia. Maarif, Vol. 9, No. 1, 9 (1), p.133.

Nu'ad, I. A. (2005). Fundamentalisme Progresif, Era Baru Dunia Islam. Jakarta: Panta Rei.

Patton, M. Q. (2002). Qualitative Research \& Evaluation Method. London, Thousand Oaks-CA, New Delhi: Sage Publications.

Qohar, A. (2011). Arah Gerakan Sosial Kelompok Fundamentalisme Salafi Lampung. Jurnal TAPIs, 7 (13), p.62-77.

Shenton, A. K. (2004). Strategies For Ensuring Trustworthiness In Qualitative Research Projects. Education for Information, 22 (22), IOS Press, p.63-75.

Suyatno. (2004). Menjelajah Demokrasi. Yogyakarta: Liebe Book. 
Taher, T. (1998). Radikalisme Agama. Jakarta: Pusat Pengkajian Islam dan Masyarakat (PPIM), IAIN.

Tomasello, T. K., Lee, Y. and Baer, A. P. (2010). 'New media' research publication trends and outlets in communication, 1990-2006. New Media \& Society, 12 (4), p.531-548. [Online]. Available at: doi:10.1177/1461444809342762.
UNDP and BAPPENAS. (2009). Measuring Democracy In Indonesia 2009 Indonesia Democracy Index. Jakarta.

Widodo, S. A. (2008). Islam dan Demokrasi Pasca Orde Baru. Jurnal Ilmu-Ilmu Sosial, 31 (65).

Zuhri, S. (2011). Revitalisasi Pancasila" dalam Pancasila, Negara Kesejahteraan, dan Ketahanan Masyarakat. Jurnal Dialog Kebijakan Publik. 